\title{
Proposing a Zakat Empowerment Program Using IDZ: Case from Cemplang Village, Bogor, Indonesia
}

\section{Khairunnajah, Irfan S. Beik and Bagus Sartono}

School of Business, IPB University

\begin{abstract}
Zakat has enormous potential for the development of a nation. Recently, The Ministry of Village, Development of Disadvantaged Areas and Transmigration targets to eradicate 5000 poor villages. However, the current number of underdeveloped villages is still high. For this, the empowerment program of BAZNAS can integrate with the local government to participate in the development of backward regions. Zakat Community Development is one of BAZNAS subsidiary aiming at community development. This study engages the index of zakat village (IDZ) to investigate the feasibility of Cemplang village in getting assisted by BAZNAS empowerment programs. This study finds that the Village is considered to get supported by zakat funds.
\end{abstract}

Keywords: zakat, community development, empowerment, IDZ

\section{INTRODUCTION}

The term zakat is from an Arabic word, which means increasing or growing. In Islam, zakat is an obligation that is ruled by Allah Subhanahuwata'ala charged to specific assets. While in language, it refers to as clean and good. According to Islamic Jurisprudence, zakat refers to the part of wealth determined by Allah to distribute to the underprivileged. According to Ibn Taimiyah; the wealth of zakat payer would be cleaner. As for its recipients, zakat will grow their wealth and cleanse their souls.

Further, Zakat is projected to reduce the poverty rate. In the Indonesian context, poverty is indeed still a big problem that demands a comprehensive solution. The Central Statistics Agency (BPS) informed the sparse population as of September 2018 was still very high at 25.674 million people or 9.66 percent of the total population of Indonesia. Considering this, it is interesting to study how zakat solves the challenge of poverty alleviation in Indonesia.

Poverty in Indonesia

Poverty rate based on islands in Indonesia as of September 2017 covered highest the Eastern Indonesia of Maluku and Papua with 21.23 percent (BPS, 2018). There were no significant changes in poverty levels in other regions, such as Sumatra with 10.44 percent, Java 9.38 percent, Sulawesi 10.93 percent, Bali and Nusa Tenggara 14.17 percent respectively, and Kalimantan with 6.18 percent.

The percentage of poor people in rural areas is always higher than that of urban areas. This makes the focus of development agencies, both government and non-government, need to give special attention to the countryside to reduce the level of poverty by taking into account the characteristics of the rural poor. Based on Presidential Regulation No. 131 of 2015 concerning 
determination of Disadvantaged Regions in 2015-2019, the government has designated 122 disadvantaged areas spread throughout Indonesia. The designation of this area is based on criteria, Indicators, and sub-Indicators of regional lagging.

In line with the Presidential Regulation, the Ministry of Village, Development of Disadvantaged Areas and Transmigration targets to eradicate 5000 poor villages as stipulated in the 2015 - 2019 National Medium-Term Development Plan. The results of 2018 Village Potential Data released by BPS note that the number of underdeveloped communities has decreased by 6,518 villages from that of 19,750 in 2014 to 13,232 in 2018. Meanwhile, developing village has increased by 3,853 from that of 51,026 in 2014 to the number of 54,879 in 2018 . Even so, the number of underdeveloped villages is still high, reaching 13,232 villages or 16.07 percent of total communities in Indonesia.

BAZNAS have been conducting the empowerment programs, which has reduced the number of poverty rate in the rural area of Indonesia. Of the program has been initiated by BAZNAS' Zakat Community Development including the productive zakat aims at providing capital for poor people to perform Small and Medium Enterprises (SMEs), such as farming, gardening, trading, and others. With so, it is expected that the welfare of the mustahik community will increase on all sides, both material, spiritual, education, and health.

\section{Puskas BAZNAS method}

BAZNAS Center of Strategic Studies (Puskas) developed an instrument to asses the feasibility of a village and community to receive zakat. The initial assessment is critical so that Baznas can know the number and population of mustahik in a town. Knowing so is expected that the empowerment program designed can be in line with the needs and capabilities of the recipient community for best result.

Based on Law No. 23 of 2011

states that BAZNAS is given the authority to manage and coordinate all zakat institutions, including LAZ in Indonesia. At present, BAZNAS has 33 representatives in all provinces in Indonesia. With this, BAZNAS has been the frontline to contribute to national development, especially in poverty alleviation.

Discussed the above, this study investigates village feasibility along with the order of priority dimensions that need to be assisted by BAZNAS through zakat empowerment programs in Cemplang, a village in Bogor, West Java, Indonesia.

\section{LITERATURE REVIEW}

\section{Empowerment and Zakat}

UNDP (United Nations Development Program, 2008) defines empowerment as a process that allows individuals or groups to change the balance of power in social, economic, and political terms in a community or community. Empowerment can refer to many activities, including increasing the awareness of the existence of social forces that pressure others and also on actions to change the pattern of power in society.

Meanwhile, Zakat according to the concept of Islam, is the foundation and pillar of the economy of a country. As the main purpose of zakat distribution, namely to improve the welfare of recipients of zakat (mustahik) or the poor. In the short term, mustahik primary needs can be fulfilled through zakat, while in the long 
run, their economic resilience will increase while stimulating economic growth. Even in many cases, it shows that many mustahik can empower and free themselves from poverty.

The benefits of zakat from community welfare development have a very noble goal, which is to raise the spirit of mutual help between each other where this will increase social solidarity among the community (Hafidhuddin and Juwaini, 2006).

\section{Index of Zakat Village (IDZ)}

The IDZ is used to measure the condition of a village for a feasibility investigation in zakat distribution. The IDZ is also used to monitor and evaluate the process of zakat distribution program in a village that the IDZ can be used by zakat management organizations to see the progress of their programs. So, the result of an assessment using the IDZ is beneficial for zakat management organizations to perform a village or community-based empowerment program. The IDZ was developed using Mixed Methods research performed by Puskas BAZNAS.

\section{Previous Study}

Studies have shown a positive impact on the utilization of zakat to develop disadvantaged communities. The study, among others, was conducted by Aan (2015), Yoghi (2015), Siti and Irsyad (2014), Rusli et al. (2013), Abdul (2012) and many other studies.

Research which has discussed the role of zakat in poverty alleviation including done by Yoghi (2015), who conducted a study on the effect of productive zakat on the empowerment of the poor with poverty index using qualitative descriptive approach. The study indicated that the Headcount
Ratio decreases from 0.8 to 0.5 . The poverty depth index also decreases where the poverty gap decreases from Rp. 547,843 to Rp. 210,020 . The Sen index value also decreases from 0.50 to 0.24 . So that overall, the study assessed that the productive zakat program by BAZNAS had been given a significant impact.

Other studies were done by Siti and Irsyad (2014), who analyzed the effect of productive zakat by BAZNAS Sumatra, on Mustahiq in Medan, Indonesia. The study indicated that productive zakat fund had been channeled in the form of loans without interest or revolving funds for small businesses. The results also suggested the differences in mustahik income before and after receiving assistance.

Similarly, Rusli, Abubakar, and Hamzah (2013) added an analysis of the impact of giving capital using productive zakat funds. The results indicated that the provision of productive zakat capital in the form of venture capital has a positive effect and could reduce the poverty rate in North Aceh, Indonesia, by $0.02 \%$. Further, Abdul (2012) found an efficient economic empowerment model to be channeled to mustahik is through the form of capital for business development with the kind of microenterprises. The research also recommended the local administration to synergize poverty reduction policies and measures through productive zakat empowerment programs.

Aan (2015) studied how zakat institutions manage and distribute religious and philanthropic funds for children's education. The results indicated that the fund had been distributed into four main programs, which are da'wah, education, social, and economy. The management of religious philanthropic funds for 
educational empowerment has been distributed in three programs including Dhuafa Children Scholarship, Sholeh Child Education Development Center, and Dhuafa School Development.

\section{RESEARCH METHODOLOGY}

This study employed both quantitative and qualitative approaches. Both primary and secondary data were utilized. Interviews and observations obtained the primary data to see the actual conditions of the object. Meanwhile, secondary data was collected by reviewing related literature.

The analysis technique used was the IDZ measurement. The IDZ was conducted to see the priority dimensions of zakat distribution that are feasible for being assisted. Descriptive analysis was used to describe the respondent's answer during the interview to further validate the quantitative analysis.

\section{Data Analysis}

Data that has been obtained was further calculated in the dashboard system of IDZ. That was done to conduct a feasibility assessment of a village to get an empowerment assistance program based on zakat funds along with a focus on the dimensions of its distribution.

The calculation in IDZ using Multi-Stage Weighted Index method, which combines each weighting stage in each index constituent component. The following formula from Puskas BAZNAS was employed;

$$
I i=\frac{(S i-S \min )}{(S \max -S \min )}
$$

Where,

$I_{i} \quad=$ Index on variable $\mathrm{i}$

$S_{i} \quad=$ actual score value on variable

measurement i

$S_{\max }=$ Maximum score
$S_{\min }=$ Minimum score

The value of IDZ is in the range between 0 and 1 . The more the IDZ value approaches 1, the more the village is not prioritized for assistance.

Conversely, the more IDZ approaches 0 , the more priority the town to assist.

\section{RESULTS AND DISCUSSION}

The feasibility of the village of Cemplang to assist with zakat funds and the priority of the distribution dimensions was analyzed using IDZ. The results indicated the value of 0.58 (Fairly Good). This value suggests that Cemplang Village, Bogor, West Java, Indonesia, is considered the assistance of zakat funds. Below is the index value of each dimension of the zakat village index in Cemplang Village, Cemplang District, Bogor Regency, West Java.

Graph 1. Index per Dimension of Cemplang Village

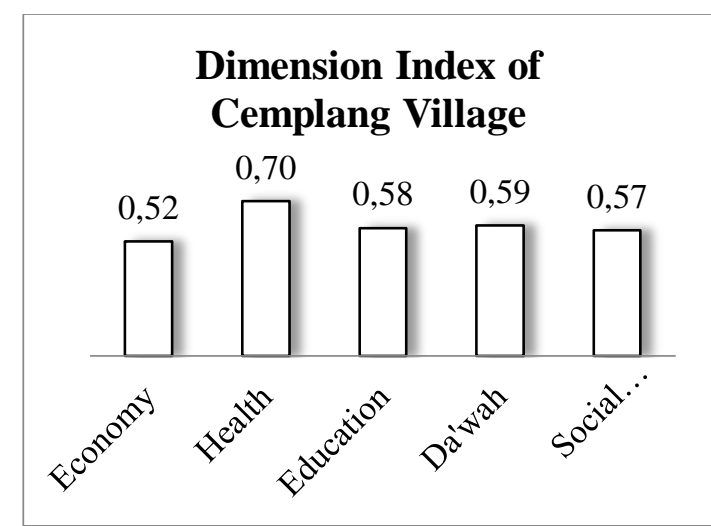

Source: Computed by the authors.

In the graph, we can see the overall dimension index value of the Village was in the range of $0.41-0.60$, which means fairly good. This value is interpreted as a value indicating that Cemplang Village can be considered for assistance. In addition to being seen from the index value, several qualitative assessments are included in the results 
of observations made by assessors when conducting field surveys as follows.

\section{Economic Dimension}

The economic dimension index in Cemplang was 0.52 , which means that it is fairly good so that it can be interpreted that the Village can be considered to be assisted with zakat funds in the economic dimension. From the calculations that have been made, the index values of variables and Indicators are obtained in the economic dimension as of table 1:

Table 1. Dimension Index, Variables and Economic Indicators

\begin{tabular}{|c|c|c|c|}
\hline Variable & $\begin{array}{l}\text { Index } \\
\text { Variable }\end{array}$ & Indicator & $\begin{array}{l}\text { Index } \\
\text { Indicator }\end{array}$ \\
\hline \multirow{3}{*}{$\begin{array}{r}\text { Productive } \\
\text { Economic Activity }\end{array}$} & \multirow[t]{3}{*}{$\mathbf{0 , 3 5}$} & Number of Featured Products & $\mathbf{0}$ \\
\hline & & Work Force Participation Rate & 1 \\
\hline & & $\begin{array}{l}\text { Number of Creative Industry Activist } \\
\text { Communities }\end{array}$ & $\mathbf{0 , 0 0}$ \\
\hline \multirow{2}{*}{$\begin{array}{r}\text { Village Trade } \\
\text { Center }\end{array}$} & \multirow[t]{2}{*}{$\mathbf{0 , 4 7}$} & Market & $\mathbf{0 , 0 0}$ \\
\hline & & Trading center & 1,00 \\
\hline \multirow{3}{*}{$\begin{array}{r}\text { Access to } \\
\text { Transportation } \\
\text { and Logistics } \\
\text { Services/Shipping }\end{array}$} & \multirow[t]{3}{*}{0,74} & Accessibility of Village Roads & 1,00 \\
\hline & & Mode of Public Transportation & 1,00 \\
\hline & & Logistics Services / Goods Delivery & $\mathbf{0 , 0 0}$ \\
\hline \multirow{3}{*}{$\begin{array}{r}\text { Access to } \\
\text { Financial } \\
\text { Institutions }\end{array}$} & \multirow[t]{3}{*}{$\mathbf{0 , 5 6}$} & $\begin{array}{l}\text { Availability and Accessibility of Financial } \\
\text { Institutions }\end{array}$ & $\mathbf{0 , 0 0}$ \\
\hline & & $\begin{array}{l}\text { Percentage of residents who owe money to } \\
\text { moneylenders }\end{array}$ & $\mathbf{0 , 7 5}$ \\
\hline & & $\begin{array}{l}\text { Percentage of population using financial } \\
\text { products/services }\end{array}$ & 1 \\
\hline
\end{tabular}

Source: computed by the authors .

Table 1 shows that in the economic dimension of Cemplang is generally in a fairly good condition. This condition can be interpreted that BAZNAS can assist the economic condition of Cemplang using zakat funds with the priority sequence of Productive Economic Activity variables with an index value of (0.35), Access to Financial Institution variables with an index value of (0.56), and Access and Logistics Services/Shipping Access variables with an index value of (0.74).

Five indicators have an index value (0.00), namely the Number of Featured Products, the Number of
Creative Industry Activists, Market Availability, Logistics Services/Goods Delivery, and Availability and Accessibility of Financial Institutions. However, not all of these Indicators have a negative effect on the economic condition of the village. As with market availability, the scope of the village does not have a large market, but residents can access the nearest market located in the sub-district within a distance of less than $4 \mathrm{~km}$ with the condition of the village road to the subdistrict already paved. This also applies to indicators of logistics services and 
access to financial institutions located in sub-districts.

The things that need to be considered by BAZNAS are Indicators of superior products that are not owned by the village. With the land area of 105 hectares, the local government has not able to maximize agricultural yields to become a superior commodity currently, the residents who are farmers only $2.9 \%$ of the total population of the village. The farming includes rice fields from cultivation the planting period to harvesting and selling individually. There are farmer groups that have previously been formed by the village government but are under-run due to the lack of assistance and capital participation.

The local agricultural commodities also include livestock commodities. Of 200 households have livestock, both large, small volumes, poultry, and other livestock. The residents who own livestock are still individual and micro scale so that the local government cannot make this a marketable commodity from Cemplang.

\section{Health Dimension}

The health dimension index value in Cemplang was 0.70, which means good so that it can be interpreted that the village is less prioritized to be assisted with zakat funds on the health dimension. From the calculation that has been done, the index values of variables and indicators are obtained in the health dimension as of table 2:

Table 2. Dimension Index, Variables and Health Indicators

\begin{tabular}{|c|c|c|c|}
\hline Variable & $\begin{array}{l}\text { Index } \\
\text { Variable }\end{array}$ & Indicator & $\begin{array}{l}\text { Index } \\
\text { Indicator }\end{array}$ \\
\hline \multirow{4}{*}{$\begin{array}{l}\text { Public } \\
\text { Health }\end{array}$} & \multirow[t]{4}{*}{$\mathbf{1 , 0 0}$} & Clean Water Facilities & $\mathbf{1 , 0 0}$ \\
\hline & & $\begin{array}{l}\text { Number of houses having bathrooms and } \\
\text { latrines }\end{array}$ & 1,00 \\
\hline & & $\begin{array}{l}\text { Number of houses have access to drinking } \\
\text { water }\end{array}$ & 1,00 \\
\hline & & Condition of Residential Houses & 1,00 \\
\hline \multirow{5}{*}{$\begin{array}{r}\text { Health } \\
\text { Services }\end{array}$} & \multirow[t]{5}{*}{$\mathbf{0 , 3 1}$} & Available facilities for Health Center & $\mathbf{0 , 0 0}$ \\
\hline & & $\begin{array}{l}\text { Available facilities for Village Maternity } \\
\text { Clinic }\end{array}$ & $\mathbf{0 , 0 0}$ \\
\hline & & Availability of Midwife & $\mathbf{0 , 0 0}$ \\
\hline & & Available facilities for Integrated Service Post & $\mathbf{1 , 0 0}$ \\
\hline & & Availability of Certified Doctors / Midwives & $\mathbf{0 , 2 5}$ \\
\hline $\begin{array}{r}\text { Health } \\
\text { Insurance }\end{array}$ & $\mathbf{0 , 7 5}$ & $\begin{array}{l}\text { Number of Village Residents Who Have } \\
\text { Health BPJS }\end{array}$ & $\mathbf{0 , 7 5}$ \\
\hline
\end{tabular}

Source: computed by the author

Table 2 shows that the health dimension of Cemplang is generally in good condition. Three indicators had an index value of 0.00 , which were the availability of community health center facilities, the availability of facilities for village maternity polyclinics, and the availability of midwives. However, 
these three indicators do not have a negative influence on the health conditions of Cemplang villagers. These three Indicators can be easily accessed by the countrymen at sub-district health facilities and services with a distance of less than $4 \mathrm{~km}$.

\section{Education Dimension}

The education index value in Cemplang Village is 0.58 , which means fairly good. The calculation we made up the index values of variables and indicators of the education dimension as of table 3:

Table 3. Dimension Index, Variables and Educational Indicators

\begin{tabular}{|c|c|c|c|}
\hline Variable & Index Variable & Indicator & $\begin{array}{l}\text { Index } \\
\text { Indicator }\end{array}$ \\
\hline \multirow[t]{2}{*}{$\begin{array}{l}\text { Education and } \\
\text { Literacy Levels }\end{array}$} & \multirow[t]{2}{*}{$\mathbf{0 , 3 9}$} & $\begin{array}{l}\text { Village Population Education } \\
\text { Level }\end{array}$ & $\mathbf{0}$ \\
\hline & & People can read and count & $\mathbf{0 , 7 5}$ \\
\hline \multirow[t]{3}{*}{$\begin{array}{r}\text { Educational } \\
\text { Facilities }\end{array}$} & \multirow[t]{3}{*}{$\mathbf{0 , 7 6}$} & $\begin{array}{l}\text { Availability of Learning Facilities } \\
\text { and Infrastructure }\end{array}$ & 1,00 \\
\hline & & $\begin{array}{l}\text { Access to the school is affordable } \\
\text { and easy }\end{array}$ & 1,00 \\
\hline & & $\begin{array}{l}\text { Availability of Adequate Number } \\
\text { of Teachers }\end{array}$ & 0,25 \\
\hline
\end{tabular}

Source: computed by the author.

Table 3 shows that in the education dimension of Cemplang, in general, is fairly good. This indicates that Cemplang has not experienced significant obstacles related to the education sector. The lowest index value possessed by the education dimension was the education level of the villagers of 0.00 . Only around 13 percent of the total population had completed 12 years of compulsory education, and only about $0.8 \%$ of the total population of the villagers had continued tertiary education.

\section{Dimension of Da'wah}

The da'wah index of Cemplang was 0.59 , which means fairly good. This could be an indication of considering Zakat assistance for the Village. The result is as of Table 4.

Table 4. Dimensions, Variables, and Indicators of Da'wah Index

\begin{tabular}{|c|c|c|c|}
\hline Variable & $\begin{array}{l}\text { Index } \\
\text { Variable }\end{array}$ & Indicator & $\begin{array}{l}\text { Index } \\
\text { Indicator }\end{array}$ \\
\hline \multirow{3}{*}{$\begin{array}{r}\text { Availability of } \\
\text { Religious Facility } \\
\text { and Assistance }\end{array}$} & \multirow[t]{3}{*}{0,63} & Mosque availability & 1,00 \\
\hline & & Access to the Mosque & 1,00 \\
\hline & & There is a Religious Companion & $\mathbf{0 , 0 0}$ \\
\hline \multirow{2}{*}{$\begin{array}{r}\text { Community } \\
\text { Religion } \\
\text { Knowledge }\end{array}$} & \multirow[t]{2}{*}{$\mathbf{0 , 4 8}$} & $\begin{array}{l}\text { Level of Al-Qur'an Literacy of the } \\
\text { Community }\end{array}$ & 0,75 \\
\hline & & $\begin{array}{l}\text { Community Awareness for Zakat and } \\
\text { Infaq }\end{array}$ & 0,25 \\
\hline
\end{tabular}




\begin{tabular}{r|lll} 
Variable & $\begin{array}{l}\text { Index } \\
\text { Variable }\end{array}$ & Indicator & $\begin{array}{l}\text { Index } \\
\text { Indicator }\end{array}$ \\
\hline Level of Religious & $\mathbf{0 , 6 3}$ & Religious Routine Activities & $\mathbf{1 , 0 0}$ \\
Activities and & & Participation in Jama'ah Prayer 5 Time & $\mathbf{0 , 2 5}$ \\
Community & & Participants in Religious Routine & $\mathbf{0 , 7 5}$ \\
Participation & & Activities & \\
\hline
\end{tabular}

Source: computed by the author.

Table 4 shows that the lowest Indicator index value possessed by the da'wah dimension was a religious companion indicator with 0.00 . This is due to the local community mostly are religious leaders. The index value of the public awareness Indicator to pay zakat and infaq as well as the Indicator of participation in congregation prayer five times also has a relatively low with 0.25 .

\section{Social and Humanity Dimensions}

The above index of Cemplang was 0.57, which means reasonably good, so that zakat funds may assist the Village on such the dimensions. Of the result, can refer to table 5 .

Table 5. Dimension Index, Variables and Social and Humanity Indicators

\begin{tabular}{|c|c|c|c|}
\hline Variable & $\begin{array}{l}\text { Index } \\
\text { Variable }\end{array}$ & Indicator & $\begin{array}{l}\text { Index } \\
\text { Indicator }\end{array}$ \\
\hline \multirow{2}{*}{$\begin{array}{r}\text { Facilities for Open } \\
\text { Community } \\
\text { Interaction }\end{array}$} & \multirow[t]{2}{*}{$\mathbf{0 , 5 3}$} & Availability of Sports Facilities & 0,25 \\
\hline & & There is a Citizen Activity Group & $\mathbf{0 , 7 5}$ \\
\hline \multirow{4}{*}{$\begin{array}{r}\text { Electricity, } \\
\text { Communication and } \\
\text { Information } \\
\text { Infrastructure }\end{array}$} & \multirow[t]{4}{*}{$\mathbf{0 , 8 9}$} & Availability of Electricity & 1,00 \\
\hline & & There is Communication Access & $\mathbf{1 , 0 0}$ \\
\hline & & There is internet access & $\mathbf{0 , 7 5}$ \\
\hline & & There is TV or Radio Broadcast & $\mathbf{0 , 7 5}$ \\
\hline $\begin{array}{r}\text { Natural Disaster } \\
\text { Mitigation }\end{array}$ & $\mathbf{0 , 0 0}$ & Disaster management & $\mathbf{0 , 0 0}$ \\
\hline
\end{tabular}

Source: computed by authors.

Table 5 informs one variable that has the lowest index value, which is a Natural Disaster Mitigation of 0.00 . This natural disaster mitigation variable needs to be considered by BAZNAS because there are educational facilities located in the village in which the areas prone to landslides. But the handling of repairs and construction of landslide affected areas is in the work area of the Bogor government. So that BAZNAS is advisable to encourage the local government action to form a natural disaster mitigation system to minimize the impact that will be generated on these educational facilities in the event of the unforeseen circumstances.

\section{CONCLUSION}

From the overall IDZ measurement we conducted to Cemplang, it can conclude the feasibility of the village to get assisted by BAZNAS program. Further, 
several things can be recommended upon the four dimensions, which are economics, education, da'wah, and social and humanity, for further assistance of Zakat fund. In addition, BAZNAS is advisable to focus on increasing the competence of rural communities in terms of developing local products. In this case, the potential of Cemplang is its agricultural commodities. This study is relevant for academics, industry experts, regulators, and other stakeholders of Zakat.

\section{REFERENCE}

BAPPENAS. (2015). Rencana Pembangunan Jangka Menengah 2015 - 2019. Jakarta (ID) : Kementerian PPN / Bappenas

BPS (Badan Pusat Statistik). (2018). Kabupaten Bogor dalam Angka 2018. Bogor (ID) : Katalog BPS 1102001.3201

BPS (Badan Pusat Statistik). (2018). Kecamatan Cibungbulang dalam Angka 2018. Bogor (ID) : Katalog BPS 1102001.3201040

BPS (Badan Pusat Statistik). (2019). Poverty. Retrieved from http://www.bps.go.id/aboutus.php ?

Hafidhuddin, D, Juwaini, A. (2006). Membangun Peradaban Zakat : Meniti jalan Kegemilangan Zakat. Jakarta (ID) : Institut Manajemen Zakat

Hafidhuddin, D, Nasar F, Kustiawan T, Beik IS, Hakiem H. (2013). Fiqh Zakat Indonesia. Jakarta (ID) : Badan Amil Zakat Nasional

Hutomo, Mardi Yatmo. (2000).

Pemberdayaan Masyarakat Dalam Bidang Ekonomi: Tinjauan Teoritik dan Implementasi. Jakarta (ID) : BAPPENAS

Kemendagri. (2018). Data Pokok Desa Cemplang 2018, www.prodeskel.binapemdes.keme ndagri.go.id diunduh 30 April 2019

Kemendagri. (2018). Laporan Tingkat Terkini Desa Cemplang 2018, www.prodeskel.binapemdes.keme ndagri.go.id diunduh 30 April 2019

Kholiq, Abdul. (2012). Pendayagunaan Zakat, Infak dan Sedekah untuk Pemberdayaan Ekonomi Masyarakat Miskin di Kota Semarang. Jurnal Riptek. 6(1): 17

Nashrullah, Aan. (2015). Pengelolaan

Dana Filantropi Untuk Pemberdayaan Pendidikan Anak Dhuafa: Studi Kasus BMH Cabang Malang Jawa Timur. Hunafa: Jurnal Studia Islamika. 12(1): 1-18

Pratama, Yoghi Citra. (2015). Peran Zakat dalam Penanggulangan Kemiskinan Studi Kasus Program Zakat Produktif Pada Badan Amil Zakat Nasional. The Journal of Tauhidnomics. 1(1): 93-104

Pusat Kajian Strategis. (2017). Indeks Desa Zakat. Jakarta: Center of Strategic Studies BAZNAS

Qardawi, Y. (2011). Hukum Zakat. Jakarta (ID) : Litera Antarnusa.

Republik Indonesia. (2011). UndangUndang No. 23 Tahun 2011 tentang Pengelolaan Zakat. Sekretariat Negara. Jakarta. Republik Indonesia. (2015). Peraturan Pemerintah No. 131 Tahun 2015 tentang Penetapan Daerah Tertinggal Tahun 2015 - 2019. Sekretariat Negara. Jakarta.

Rusli., Hamzah, Abubakar., Syahnur, Sofyan. (2013). Analisis Dampak Pemberian Modal Zakat Produktif Terhadap Pengentasan Kemiskinan di Kabupaten Aceh Utara. Jurnal Ilmu Ekonomi Pascasarjana Universitas Syiah Kuala. 1(1): 56-63 
Sumodiningrat, Goenawan. (1999).

Pemberdayaan Masyarakat dan Jaring Pengaman Sosial. Jakarta (ID) : Gramedia

UNDP (United Nations Development Programme). (2008). Initiatives on Legal Empowerment of the Poor. New York : UNDP

Utami, Siti Halida., dan Lubis, Irsyad. (2014). Pengaruh Pendayagunaan Zakat Produktif Terhadap Pemberdayaan Mustahiq di Kota Medan. Jurnal Ekonomi dan Keuangan. 2(6): 353-36 
